\title{
Review
}

\section{Getting it right: Culturally safe approaches to health partnership work in low to middle income countries}

a.taylor7@brighton.ac.uk

School of Health Sciences, University of Brighton, Village Way, Falmer, Brighton BN1 9PH, UK

\section{Abstract}

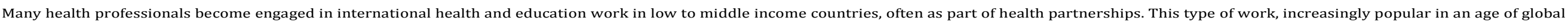

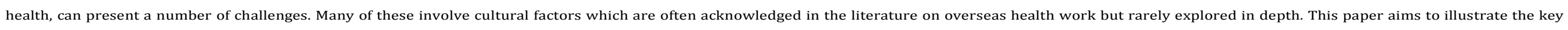

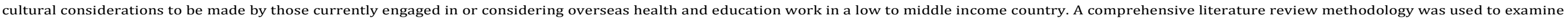

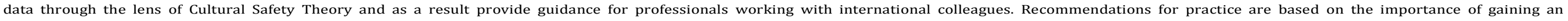
understanding of the host country's history and social context and of professionals examining their own individual worldviews.

Keywords: Cultural safety; Health partnerships; International working; Low to middle income countrie

\section{Introduction}

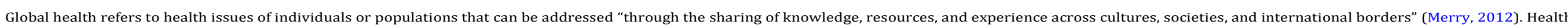

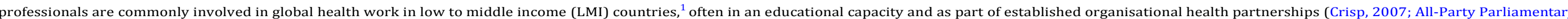
Group [APPG] on Global Health, 2013).

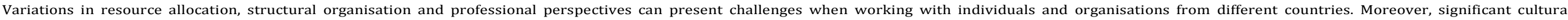

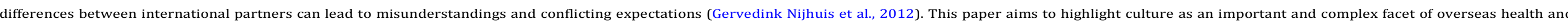
education work. It will summarise key cultural considerations to be made by those currently engaged in or considering such work.

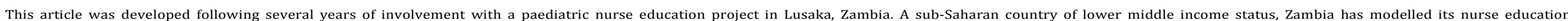

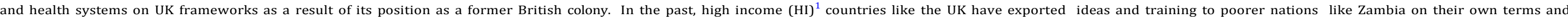
without much consideration of the very specific needs of those countries-very much a 'top down' approach (Crisp, 2010)

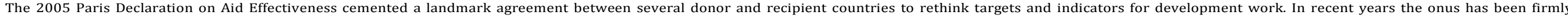

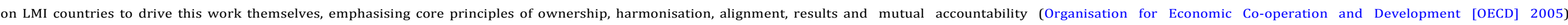

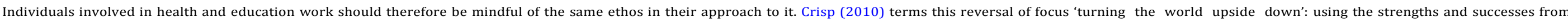

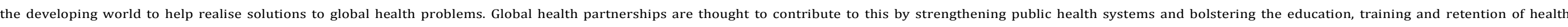

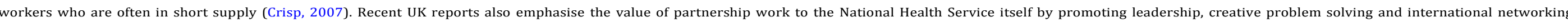
(APPG on Global Health 2013, Department of Health/Department for International Development [DH/DFID] 2014, International Health Coordination Centre [IHCC] 2014).

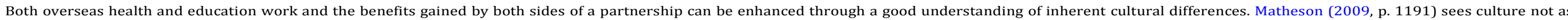

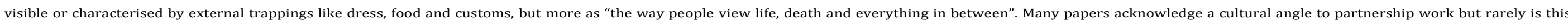
explored in depth. Culture per se is not often examined as a key force within professional interaction and this presents a gap that this paper seeks to fill. 


\subsection{Theoretical framework}

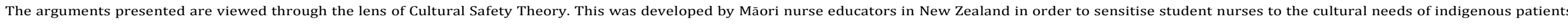

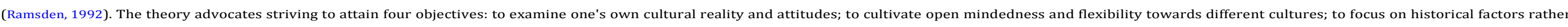

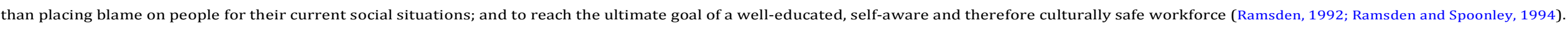

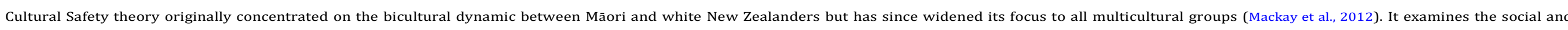

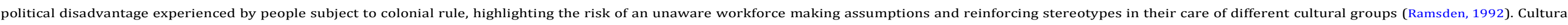

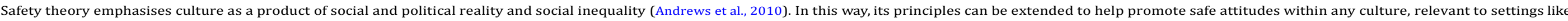
Zambia which may have been colonised in the past by richer Western nations and where health partnership work is currently practised.

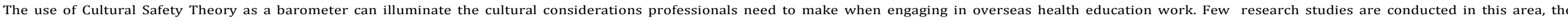

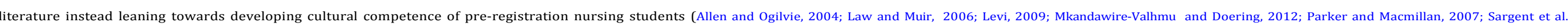
2005).

\section{Design}

\subsection{Methodology}

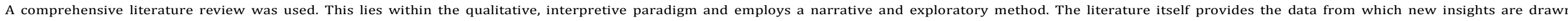

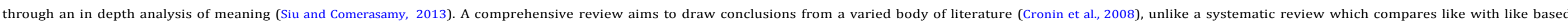
on study methodology.

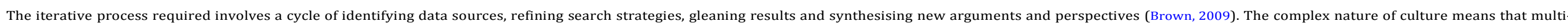

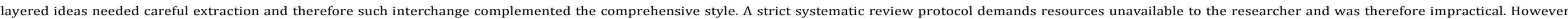
efforts were made to ensure a high level of discipline and uphold systematic principles (Aveyard, 2010; Cronin et al., 2008; Siu and Comerasamy, 2013).

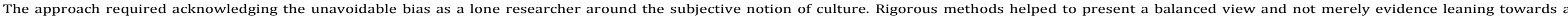
personal stance, important for transparency and integrity. The secondary nature of the data meant no direct contact with research participants and therefore no higher ethical approval was required.

\subsection{Key search terms}

\section{nurs $^{2 *}$ OR health \\ education OR training}

cultural AND (sensitivity OR competence OR awareness OR blindness OR understanding OR diversity OR congruence OR relativism OR imperialism)

"partnership working" OR collaboration

international OR overseas

"global health partnerships"

ethic ${ }^{*} *$ OR "best practice"

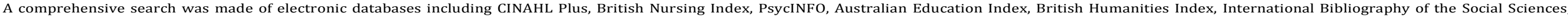
SciDevNet and System for Information on Grey Literature in Europe. 
Table 1

alt-text: Table 1

\section{Included}

Papers from 2003 to 2013 (one highly relevant dated 1999)

Studies of experience, process, impact or implications of working directly with professionals in low to middle income countries

Grey literature on global health partnership working or international nursing/health education

\section{Excluded}

Papers not in English

Literature whose cultural content focused exclusively on patient care, pre- registration health education or overseas electives

Papers on health systems, workforce development and other strategic themes

Literature on school education

84 initial results were identified from these searches. After review of each abstract for relevance, a final dataset of 38 papers for inclusion was reached (29 research papers and nine pieces of grey literature).

\subsection{Critical appraisal}

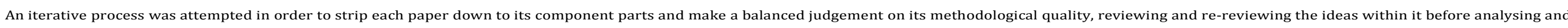

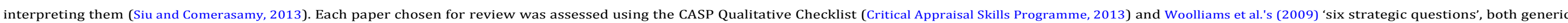

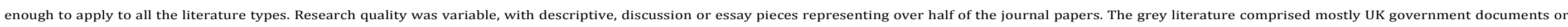
resources from professional organisations.

\subsection{Data analysis}

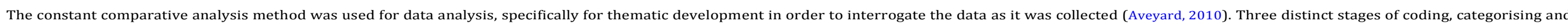
theming were used to recognise patterns and interlinking relationships among the data (Thomas and Harden, 2008).

\section{Results}

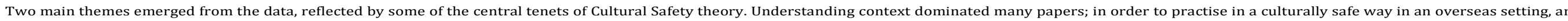

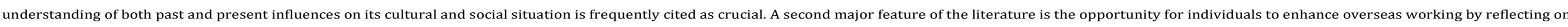

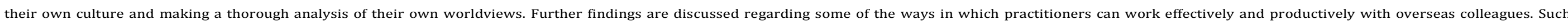

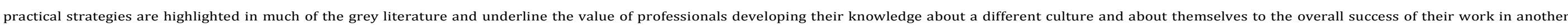
setting.

\section{Understanding context}

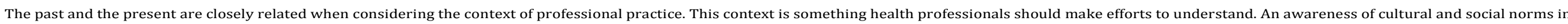

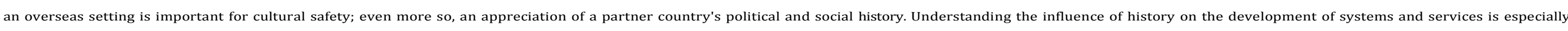

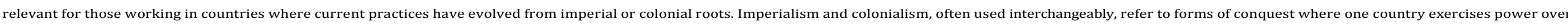

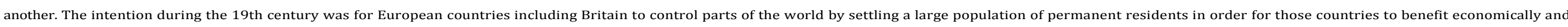
strategically (Kohn, 2012).

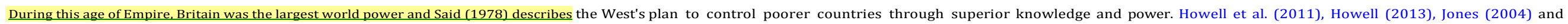
Rafferty and Solano (2007) highlight the preservation of this political ideology in their analyses of government documents and nurses' personal 


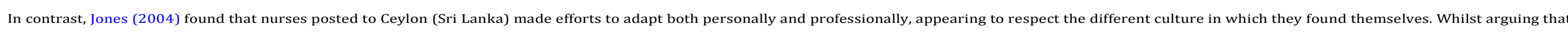

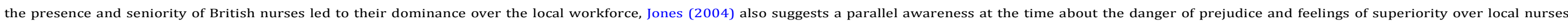
Ramsden (2000) sees power relations at the core of Cultural Safety Theory, and maintains that an effort to avoid power imbalances is central to working in a culturally safe way.

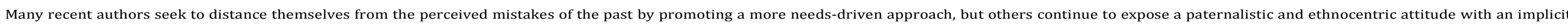

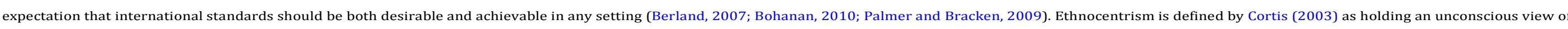

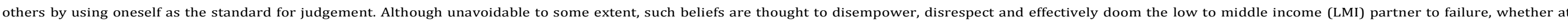

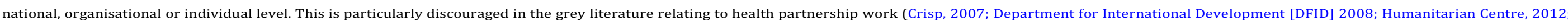
Tropical Health Education Trust [THET] 2012).

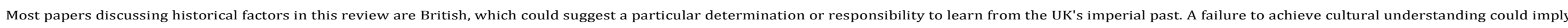

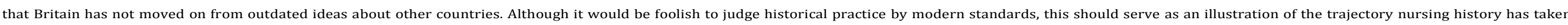
globally. The continuing power of this history in influencing individuals' worldviews will be discussed later and also linked back to the principles of Cultural Safety theory.

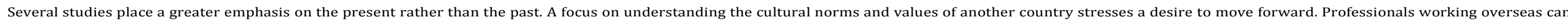

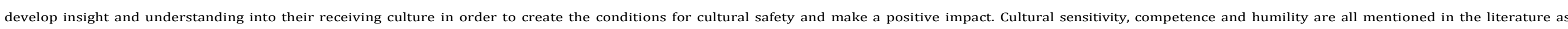

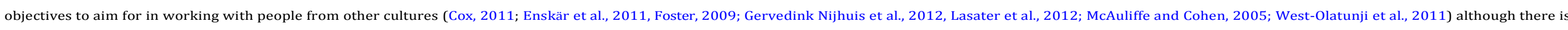

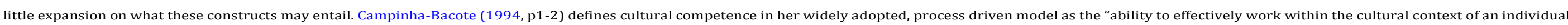
or community from a diverse cultural or ethnic background".

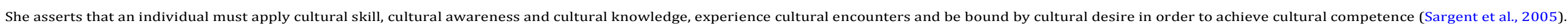
Time and passive adaptation to different cultural norms is not enough.

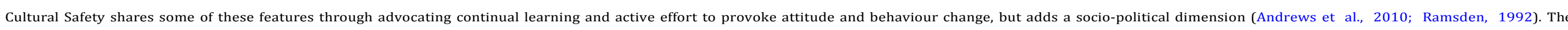

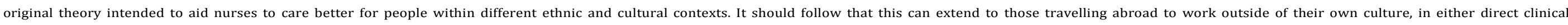
practice or education.

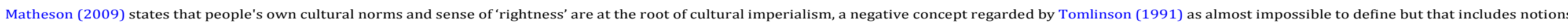

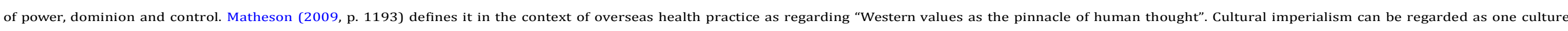
considering itself superior to others, judging them against its own standards.

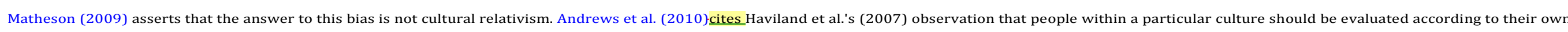

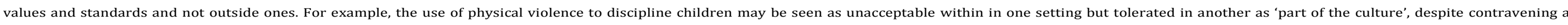

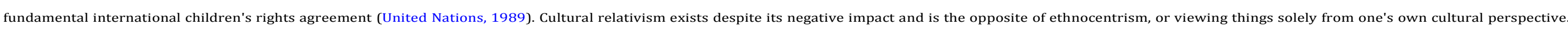
Matheson (2009) argues that not all cultural norms in health should be accepted as valid, regardless of moral or ethical implications, simply in order to avoid the dominant Western view.

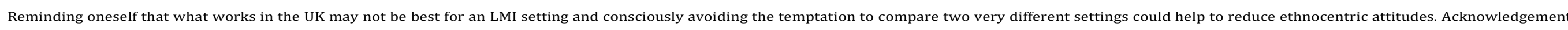

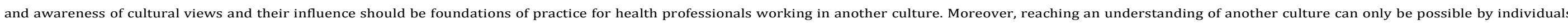
consciously reflecting on themselves and their own culture.

\section{Understanding self}




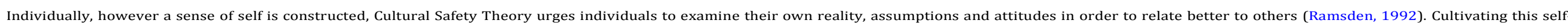

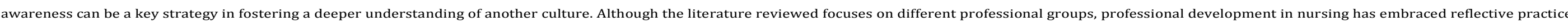

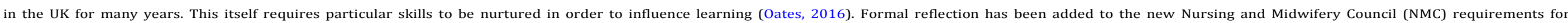
revalidation in the UK (NMC, 2016); the expectation for nurses to embed such skills in their practice is now even more explicit

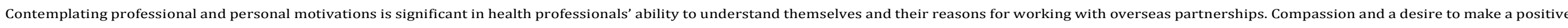

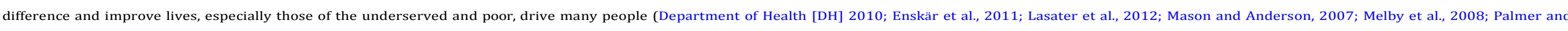

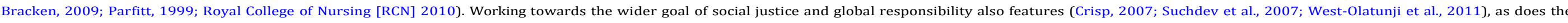

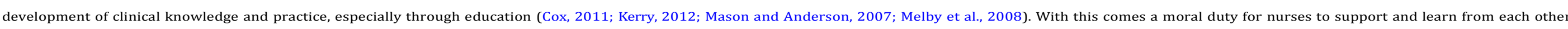

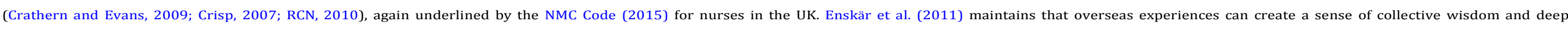

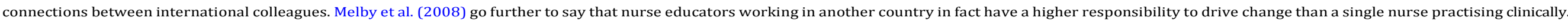

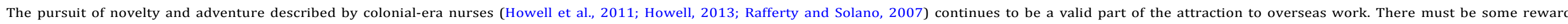

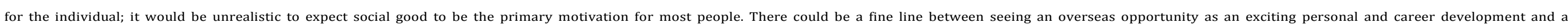
chance to explore exotic new territory principally for one's own gain.

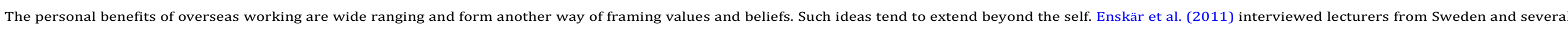

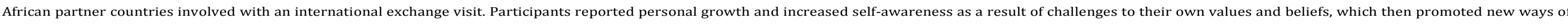

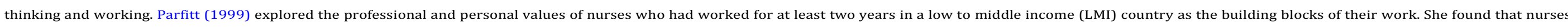
either modified their personal values, principally those relating to gender, race and power, to create an 'enabling environment', or promoted dependence through a lack of insight into their own worldviews.

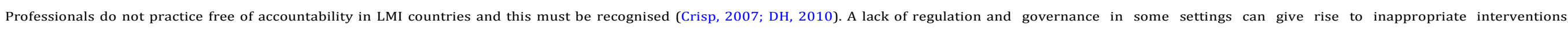

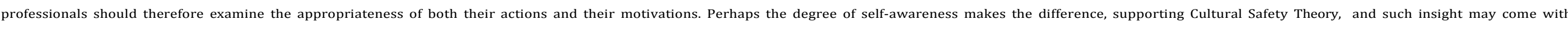

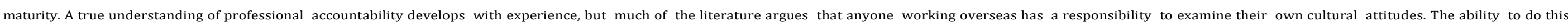
may depend heavily on each individual's insight and emotional intelligence.

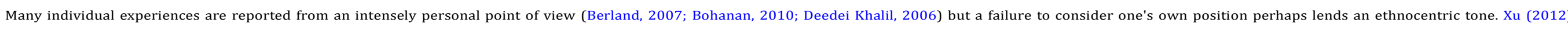

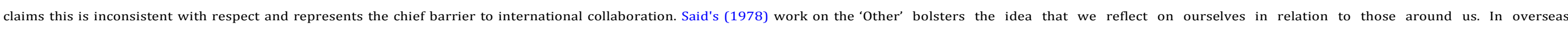

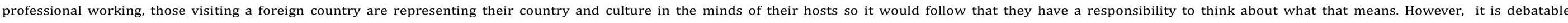
whether this examination is developed as a result of the experiences, recommended as a measure to prevent problems, or both.

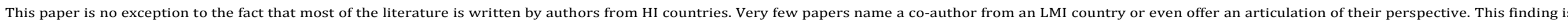

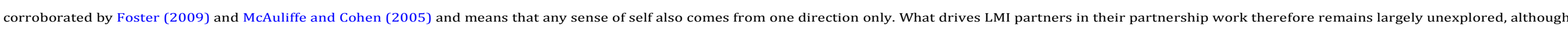

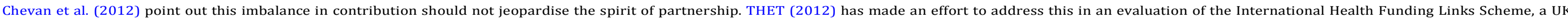
government established initiative. Although written by Western consultants, it allows a rare insight by focusing exclusively on the perspective of partners in Uganda, Malawi and Zambia.

\section{Challenges and suggested strategies}

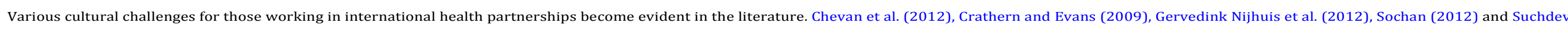

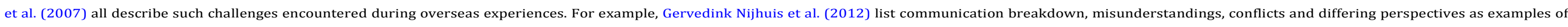
difficulties rooted in cultural dissimilarity. Clearly, these findings are about more than language; any breakdown in communication can be problematic, regardless of linguistic differences.

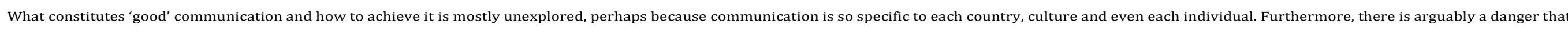

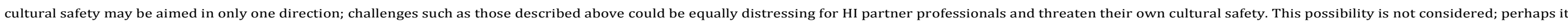




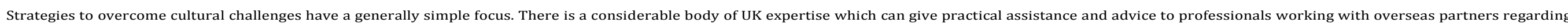

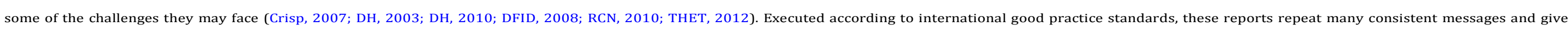
practical and concrete advice, providing a platform for the complex cultural and historical learning discussed earlier.

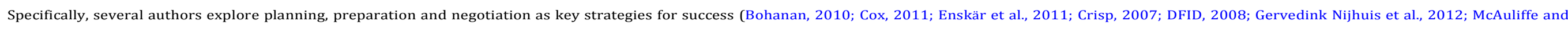

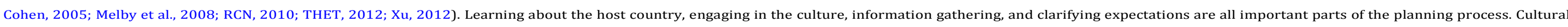

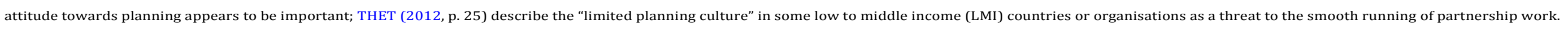

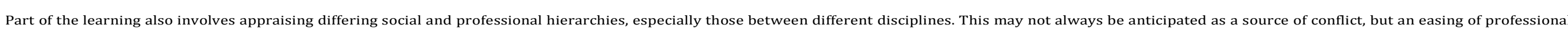

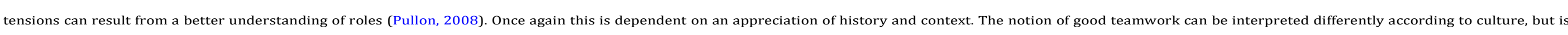

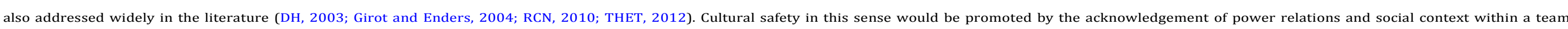
(Ramsden, 2000).

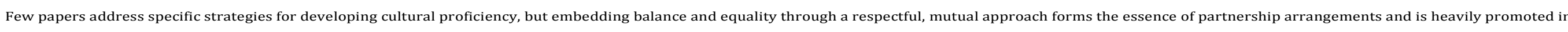

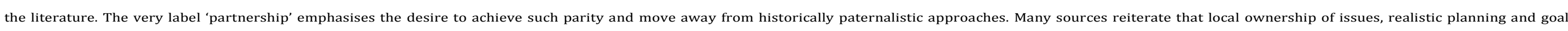

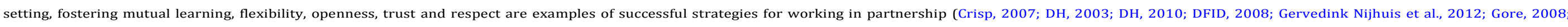
Humanitarian Centre, 2012; Mason and Anderson, 2007; Melby et al., 2008; RCN, 2010; THET, 2012; Xu, 2012).

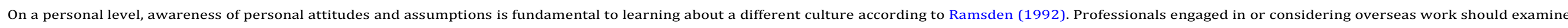

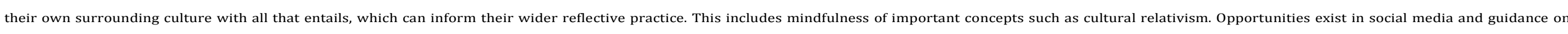
working overseas from organisations such as the RCN to advise professionals on these subtle but important learning points.

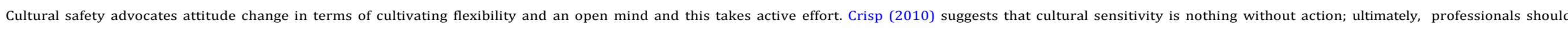
be judged more on their behaviour than simply on their views.

\section{Conclusion}

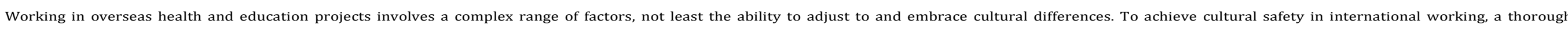
understanding of the historical and contemporary context of the setting is recommended across the literature. The evidence broadly suggests that failure to achieve this may compromise cultural safety.

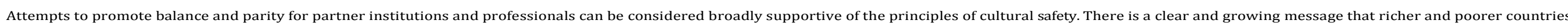
are 'in it together', with local needs a firm priority.

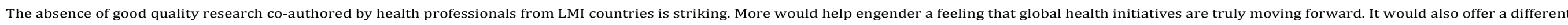
view by strengthening the voice of those less typically heard in the debate; and highlight the cultural safety of all parties, not only those previously disadvantaged, as an interest worth protecting.

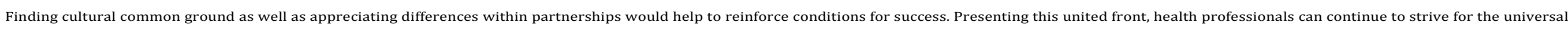
goal of improved global health.

\section{Conflict of interest statement}

None.

\section{Acknowledgements}

Thanks to Kate Law, Deputy Head, School of Health Sciences, University of Brighton. 


\section{References}

Allen M. and Ogilvie L., Internationalization of higher education: potentials and pitfalls for nursing education, Int. Nurs. Rev. 51, 2004, 73-80.

All-Party Parliamentary Group on Global Health, Improving Health at Home and Abroad: How Overseas Volunteering from the NHS Benefits the UK and the World, 2013, [Online]. Available from:

http://rstmh.org/sites/default/files/Improving\%20Health\%20at\%20Home\%20and\%20Abroad\%20-\%20Final\%20Report-2.pdf, Accessed 10/01/15.

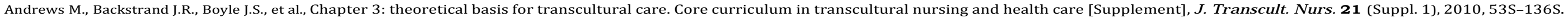
Aveyard H., Doing a Literature Review in Health and Social Care: a Practical Guide, Maidenhead2010, Open University Press.

Berland A., Volunteers supporting nurse education in Bangladesh, Singap. Nurs. J. 34, 2007, 7-9.

Bohanan J., Application of the nursing process in a clinical mentoring experience in Lesotho, Africa, Home Health Care Manag. 22, 2010, 349-353.

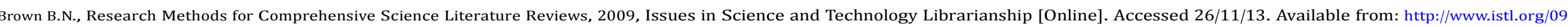

spring/experts1.html.

Campinha-Bacote J., Cultural competence in mental health nursing: a conceptual model, Nurs. Clin. N. Am. 29 (1), 1994, 1-7, March.

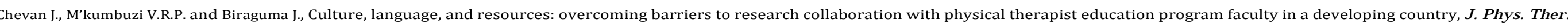
Educ. 26 (1), 2012, 50-54, Winter.

Cortis J.D., Culture, values and racism: application to nursing, Int. Nurs. Rev. 50, 2003, 55-64.

Cox K., Evaluating the effectiveness of intercultural teachers, Nurs. Educ. Perspect. 32 (2), 2011, 102-106, March/April.

Crathern L. and Evans D., Delivering a neonatal and child health teaching programme in sub-Saharan Africa, Infant 5 (1), 2009, 8-11.

Crisp N., Global Health Partnerships: the UK Contribution to Health in Developing Countries, 2007, [Online]. Available

from: http://www.dh.gov.uk/en/Publicationsandstatistics/Publications/PublicationsPolicyAndGuidance/DH_065374, Accessed 30/5/2013.

Crisp N., Turning the World Upside Down: the Search for Global Health in the 21st Century, 2010, Royal Society of Medicine Press Ltd.; London.

Critical Appraisal Skills Programme, Qualitative Research Checklist 31.05.13, 2013, [Online]. Available from: http://www.casp-uk.net/, Accessed 13/10/2013.

Cronin P., Ryan F. and Coughlan M., Undertaking a literature review: a step-by-step approach, Br. J . Nurs. 17 (1), 2008, 38-43.

Deedei Khalil D., Experiences of teaching nursing in four countries, Nurs. Forum 41 (2), 2006, 88-94, April-June.

Department for International Development Health Resource Centre, Evaluation of Links between North and South Healthcare Organisations, 2008, [Online]. Available from: http://www.build-

online.org.uk/documents/Evaluation\%20of\%20links\%20between\%20N\%20and\%20S\%20healthcare\%20orgs\%20-\%20DFID\%202008-1.pdf, Accessed 25/01/2014.

Department of Health, International Humanitarian and Health Work: Toolkit to Support Good Practice, 2003, [Online]. Available

from: http://www.fph.org.uk/uploads/international_humanitarian_and_healthwork_toolkit.pdf, Accessed 10/12/2013.

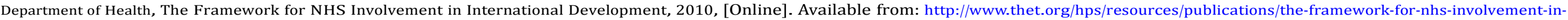
international-development, Accessed 06/11/2013.

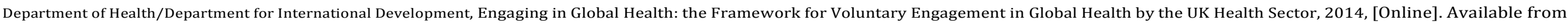

https://www.gov.uk/government/uploads/system/uploads/attachment_data/file/352928/Engaging_in_Global_Health_1_.pdf, Accessed 05/11/2014.

Enskär K., Johansson I., Ljusegren G. and Widäng I., Lecturers' experiences of participating in an international exchange, Nurse Educ. Today 31, 2011, 541-546. 
Foster J., Cultural humility and the importance of long-term relationships in international partnerships, J . Obstetric Gynaecol. Neonatal Nurs. 38, $2009,100-107$.

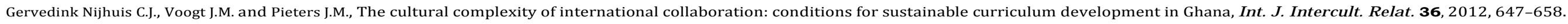
Girot E.A. and Enders B.C., International educational partnership for practice: Brazil and the United Kingdom, J. Adv. Nurs. 46 (2), $2004,144-151$.

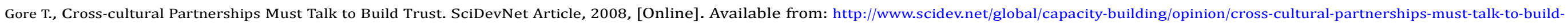
tru.html, Accessed 04/12/2013.

Howell J., Rafferty A.M. and Snaith A., (Author)ity abroad: the life writing of colonial nurses, Int. J . Nurs. Stud. 48, 2011, $1155-1162$.

Howell J., Nursing empire: travel letters from Africa and the Caribbean, Stud. Travel Writ. 17 (1), 2013, 62-77.

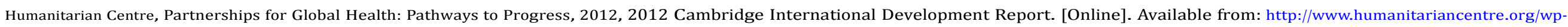

content/uploads/2010/07/Partnerships-for-global-health_pathways-to-progress.pdf, Accessed 22/07/2013.

International Health Coordination Centre, A Charter for International Health Partnerships in Wales, 2014, [Online]. Available

from: http://www.internationalhealth.wales.nhs.uk/sitesplus/documents/1100/IHCC\%20Charter\%20for\%201HP\%20\%28Interactive\%29\%20E.pdf, Accessed 05/11/2014.

Jones M., Heroines of lonely outposts or tools of the empire? British nurses in Britain's model colony: Ceylon, 1878-1948, Nurs. Inq. 11, 2004, 148-160.

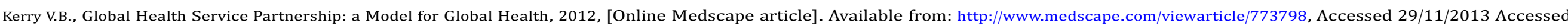
$04 / 12 / 2013$.

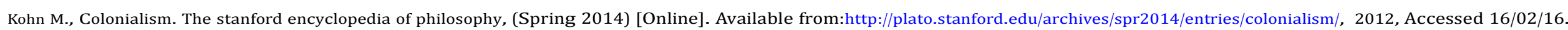

Lasater K., Upvall M., Nielsen A., et al., Global partnerships for professional development: a cambodian exemplar, J. Prof. Nurs. 28 (1), $2012,62,01$ Jan.

Law K. and Muir N., The internationalisation of the nursing curriculum, Nurse Educ. Pract. 6, 2006, 149-155.

Levi A., The ethics of nursing student international clinical experiences, J. Obstetric Gynaecol. Neonatal Nurs. 38, 2009, 94-99.

McAuliffe M.S. and Cohen M.Z., International nursing research and educational exchanges: a review of the literature, Nurs. Outlook 53, $2005,21-25$.

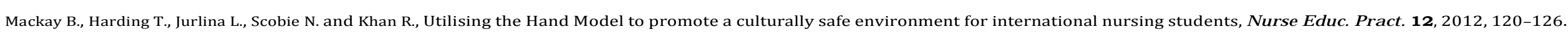

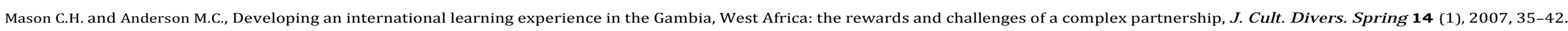

Matheson D., A right to health: medicine as Western cultural imperialism?, Disabil. Rehabilitation 31 (14), 2009, 1191-1204.

Melby C.S., Dodgson J.E. and Tarrant M., The experiences of Western expatriate nursing educators teaching in Eastern Asia, J . Nurs. Scholarsh. 40 (2), $2008,176-183$.

Merry L., Global health for Nursing...and nursing for global health, DecCan. J . Nurs. Res. 44 (4), 2012, 20-35.

Mkandawire-Valhmu L. and Doering J., Study abroad as a tool for promoting cultural safety in nursing education, J. Transcult. Nurs. 23 (1), $2012,82-89$.

Nursing and Midwifery Council, The Code, 2015, [Online]. Available from: https://www.nmc.org.uk/globalassets/sitedocuments/nmc-publications/nmc-code.pdf, Accessed 20/02/2016.

Nursing and Midwifery Council, Welcome to Revalidation, 2016, [Online]. Available from: http://revalidation.nmc.org.uk/welcome-to-revalidation/, Accessed 20/02/2016.

Oates J., Becoming a learning professional, Community Pract. 89 (1), 2016, 16-17, January.

Organisation for Economic Co-operation and Development, The Paris Declaration on Aid Effectiveness: Five Principles for Smart Aid, 2005, [Online]. Available

from: http://effectivecooperation.org/files/resources/Paris\%20Declaration\%20in\%20Brief\%20ENGLISH.pdf, Accessed 29/11/2013. 
Palmer S.P. and Bracken D.R., The Ecuador Project: the five 'R's of an education collaboration, Int. Nurs. Rev. 56, 2009, 470-475.

Parfitt B., Working across cultures: a model for practice in developing countries, Int. J . Nurs. Stud. 36, 1999, 371-378.

Parker V. and Macmillan M., Challenges facing internationalisation of nursing practice, nurse education and nursing workforce in Australia, Contemp. Nurse 24, $2007,128-136$.

Pullon S., Competence, respect and trust: key features of successful interprofessional nurse-doctor relationships, J. Interprofessional Care 22 (2), 2008, 133-147, March.

Rafferty A.M. and Solano D., The rise and demise of the Colonial Nursing Service: British nurses in the colonies, 1896-1966, Nurs. Hist. Rev. 75, 2007, 147-154.

Ramsden I., Teaching cultural safety, N. Z. Nurs. J. 1992, 21-23, June.

Ramsden I., Defining cultural safety and transcultural nursing 6, 2000, Kai Tiaki; Nursing New Zealand, (8), Sept, 4.

Ramsden I. and Spoonley P., The cultural safety debate in nursing education in Aotearoa, N. Z. Annu. Rev. Educ. 3, 1994, $161-174$.

Royal College of Nursing, Working with Humanitarian Organisations: a Guide for Nurses, Midwives and Health Care Professionals, 2010, [Online]. Available

from: http://www.rcn.org.uk/_data/assets/pdf_file/0007/347920/Working_with_humanitarian_organisations.2010.pdf, Accessed 15/02/2013.

Said E., Orientalism, 1978, Penguin; London.

Sargent S.E., Sedlak C.A. and Martsolf D.S., Cultural competence among nursing students and faculty, Nurse Educ. Today 25 (3), 2005 , 214-221, Apr.

Siu C. and Comerasamy H., Doing a Research Project in Nursing and Midwifery: a Basic Guide to Research Using the Literature Review Methodology, 2013, Sage; London.

Sochan A., Relationship building through the development of international nursing curricula: a literature review, Int. Nurs. Rev. 55, 2012, 192-204.

Solano D. and Rafferty A.M., Can lessons be learned from history? The origins of the British imperial nurse labour market: a discussion paper, Int. J . Nurs. Stud. 44, $2007,1055-1063$.

Suchdev P., Ahrens K., Click E., et al., A model for sustainable short-term international medical trips, Ambul. Pediatr. 7, 2007, 317-320.

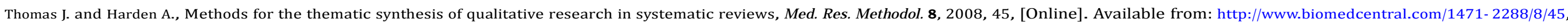
Accessed 02/11/2013.

Tomlinson J., Cultural Imperialism, 1991, Continuum; London.

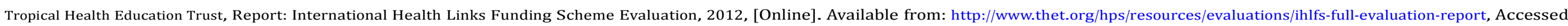
$06 / 11 / 2013$.

United Nations, United Nations Convention on the Rights of the Child (UNCRC), 1989, United Nations; Geneva, [Online]. Available from: http://www.unicef.org.uk/Documents/Publicationpdfs/UNCRC_PRESS200910web.pdf, Accessed 01/02/2015.

West-Olatunji C., Goodman R.D., Mehta S. and Templeton L., Creating cultural competence: an outreach immersion experience in southern Africa, Int. J . Adv. Couns. 33, 2011, 335-346.

Woolliams M., et al., 'Be More Critical!' a Practical Guide for Health and Social Care Students, 2009, Oxford Brookes University, [Online]. Available

from: http://www.brookes.ac.uk/library/health/healthcareguides.html, Accessed 13/10/2013.

Xu Y., International nursing exchange and collaboration with China: a perspective from the South and the East, Nurs. Forum 47 (4), 2012, 236-244, October-December.

\section{Footnotes}

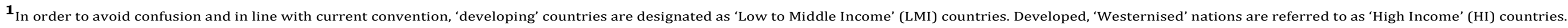

Queries and Answers 


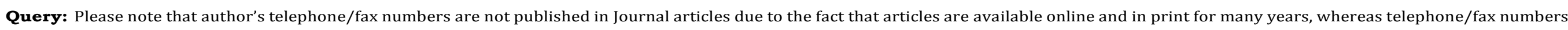
are changeable and therefore not reliable in the long term.

Answer: Understood

Query: Please provide a caption for Table [1]

Answer: Caption for Table 1: Inclusion and Exclusion Criteria

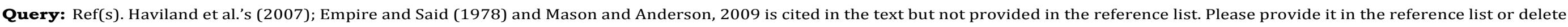
these citations from the text.

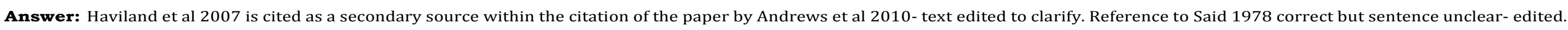
Mason and Anderson incorrectly appears in text as 2009- edited

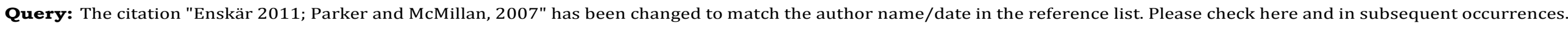

Answer: Checked

Query: Please confirm that given names and surnames have been identified correctly.

Answer: Yes

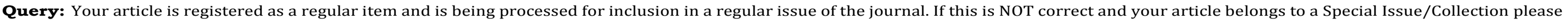
contact s.gudiseva@elsevier.com immediately prior to returning your corrections.

Answer: Yes 